\title{
Bacteria Responsible for Nitrate-dependent Antimonite Oxidation in Antimony-contaminated Paddy Soil Revealed by the Combination of DNA-SIP and Metagenomics
}

\section{Miaomiao Zhang}

Guangdong Institute of Eco-Environmental and Soil Sciences

\section{Zhe Li}

Wuhan Institute of Technology

\section{Max M. Häggblom}

Rutgers The State University of New Jersey

\section{Lily Young}

Rutgers The State University of New Jersey

\section{Fangbai Li}

Guangdong Institute of Eco-Environmental and Soil Sciences

\section{Zijun He}

Guangdong Institute of Eco-Environmental and Soil Sciences

Guimei Lu

Guangdong Institute of Eco-Environmental and Soil Sciences

Rui Xu

Guangdong Institute of Eco-Environmental and Soil Sciences

Xiaoxu Sun

Guangdong Institute of Eco-Environmental and Soil Sciences

\section{Lang Qiu}

Guangdong Institute of Eco-Environmental and Soil Sciences

Weimin Sun ( $\nabla$ swmmicrobe@163.com )

Guangdong Institute of Eco-Environmental and Soil Sciences https://orcid.org/0000-0002-3456-8177

\section{Research}

Keywords: Nitrate-dependent antimonite oxidation, Nitrate-dependent Sb(III)-oxidizing bacteria, DNA-SIP, amplicon and shotgun metagenomics

Posted Date: September 17th, 2020 
DOI: https://doi.org/10.21203/rs.3.rs-78069/v1

License: (c) (1) This work is licensed under a Creative Commons Attribution 4.0 International License. Read Full License

Version of Record: A version of this preprint was published at Soil Biology and Biochemistry on May 1st, 2021. See the published version at https://doi.org/10.1016/j.soilbio.2021.108194. 


\section{Abstract}

Background: Antimonite ( $\mathrm{Sb}(\mathrm{III})$ ) oxidation (SbO) can decrease the toxicity of antimony (Sb) and its uptake into plants (e.g., rice), thus serving an ecological role in bioremediation of Sb contamination. In some anoxic environments, $\mathrm{Sb}$ (III) can be oxidized coupled with nitrate as the electron acceptor. Here we investigate the potential for nitrate-dependent $\mathrm{SbO}$ in Sb contaminated rice paddies and identify nitratedependent $\mathrm{Sb}$ (III)-oxidizing bacteria (SbOB) using stable isotope probing (SIP) coupled with amplicon and shotgun metagenomic sequencing.

Results: Anaerobic SbO was exclusively observed in the paddy soil amended with both $\mathrm{Sb}$ (III) and $\mathrm{NO}_{3}$, whereas no apparent SbO was detected in the soil amended with $\mathrm{Sb}$ (III) only. The increasing abundance of the arsenite oxidase $(a i O A)$ gene suggests that nitrate-dependent $\mathrm{SbO}$ was catalysed by microorganisms harbouring the aioA gene. After 60-day DNA-SIP incubation, obvious shift in the aioA gene to heavy DNA fractions only in the treatment amended with ${ }^{13} \mathrm{C}-\mathrm{NaHCO}_{3}, \mathrm{Sb}(\mathrm{III})$ and $\mathrm{NO}_{3}{ }^{-}$suggested the incorporation of ${ }^{13} \mathrm{C}$ by nitrate-dependent SbOB. Accordingly, DNA-SIP identified a number of putative nitrate-dependent SbOB in the paddy soil, including Azoarcus, Azospira and Chelativorans. Metagenomic analysis further revealed that they contained aio $A$ gene and genes involved in denitrification and carbon fixation, supporting their capability for nitrate-dependent SbO.

Conclusions: These observations in this study suggested the occurrence of nitrate-dependent $\mathrm{SbO}$ in paddy soils. A number of putative nitrate-dependent SbOB (i.e., Azoarcus, Azospira and Chelativorans) were reported here, which expands our current knowledge regarding the diversity of nitrate-dependent SbOB. In addition, this study provides a proof of concept using DNA-SIP to identify nitrate-dependent SbOB.

\section{Background}

Antimony (Sb) is a toxic metalloid belonging to Group 15 in the periodic table and share similar chemical properties with arsenic (As) [1]. Sb has been classified as a suspected carcinogen [2] and chronic exposure can cause damage to various organ systems including the heart, lung, liver and kidney [3]. Although $\mathrm{Sb}$ is ubiquitously present at low concentrations $\left(0.2-1 \mu \mathrm{g} \mathrm{g}^{-1}\right)$ in nature [4], anthropogenic activities such as mining and smelting have led to $S b$ contamination in the environment [5-7]. Typically, two oxidation states of $\mathrm{Sb}$, namely antimonite $(\mathrm{Sb}(\mathrm{III}))$ and antimonate $(\mathrm{Sb}(\mathrm{V}))$, are the main forms of $\mathrm{Sb}$ in nature $[9,10]$. The mobility, bioavailability and toxicity of Sb strongly depends on its oxidation state, for instance, $\mathrm{Sb}(\mathrm{V})$ is less toxic than $\mathrm{Sb}(\mathrm{III})$ [11-13].

Microorganisms are major drivers changing Sb speciation in the environment [15]. Compared to our extensive knowledge regarding As microbiology $[16,17]$, microbially-mediated Sb cycling has only attracted attention recently [18-20]. Owing to the higher toxicity of $\mathrm{Sb}(I I I)$ than $\mathrm{Sb}(\mathrm{V})[12,21]$, oxidation of $\mathrm{Sb}(\mathrm{III})$ to $\mathrm{Sb}(\mathrm{V})$ can decrease the toxicity of $\mathrm{Sb}$ and is thus of great interest. Previous studies reported that heterotrophic Sb-resistant bacteria can oxidize Sb(III) as cellular detoxification mechanism [22-24]. 
However, Stibiobacter senarmontii was reported to be capable of growing chemoautotrophically using the energy obtained from SbO [25]. Currently, over 60 bacterial strains have been reported to oxidize $\mathrm{Sb}$ (III) via arsenite oxidase AioAB or antimonite oxidase AnoA [26]. Southwest China is the major rice producing area and also a key $\mathrm{Sb}$ mining area. The $\mathrm{Sb}$ mining activities have caused frequent contamination of rice fields. For instance, it has been reported that rice is a major route for $\mathrm{Sb}$ exposure near Xikuangshan $\mathrm{Sb}$ mining area, contributing to over $30 \%$ of the daily intake of the $S b$ to exposed population [25]. Therefore, $\mathrm{Sb}$ contamination in rice paddies $\mathrm{n}+$ ear $\mathrm{Sb}$ mining area is an important environmental issue. In addition, rice is found to be more efficient in uptake of $\mathrm{Sb}$ (III) than of $\mathrm{Sb}(\mathrm{V})[25,26]$. Hence, $\mathrm{SbO}$ may be an important biogeochemical process that attenuates $\mathrm{Sb}$ toxicity in rice paddies and decreases the translocation and accumulation of $\mathrm{Sb}$ in the rice. However, the anoxic conditions in some habitats such as river sediment and flooded rice paddies may hinder SbO because of the lack of $\mathrm{O}_{2}$. Notably, nitrate is an alternative to $\mathrm{O}_{2}$ as an oxidant that can support $\mathrm{SbO}$ under anoxic conditions. Indeed, three anaerobic $\mathrm{Sb}$ (III)-oxidizing bacteria (SbOB) (i.e., Hydrogenophaga taeniospiralis strain IDSBO-1, Ensifer sp. NLS4 and Sinorhizobium sp. GW3) have been isolated using nitrate as the electron acceptor $[13,18,27]$. The anoxic conditions and high concentrations of nitrate caused by $\mathrm{N}$ fertilization would allow rice paddies to facilitate nitrate-dependent SbO. However, nitrate-dependent SbO has never been reported in rice paddies so far.

Xikuangshan Sb mine, designated as "the World Antimony Capital", located in Lengshuijiang City in Hunan Province of China, is the world largest Sb deposit with over 120 years of mining history and environmental contamination. In order to investigate nitrate-dependent SbO in rice paddy soils and identify the bacteria responsible for this process, Sb-contaminated paddy samples were collected near the Xikuangshan mining area $[28,29]$. It is proposed that the long-term Sb contaminated may enrich Sbmetabolising bacteria including nitrate-dependent SbOB and makes these Sb-contaminated rice paddy soils ideal for this study. Although three nitrate-dependent $\mathrm{SbOB}$ have been isolated and identified so far $[13,18,27]$, their overall diversity and distribution in soil, especially in rice paddy soil, is not known. Culture-independent DNA-stable isotope probing (SIP) incubations can link microbial identity with function in environment and enable a greater understanding of active microbial communities involved in the process under study [30]. Indeed, SIP has been used to identify chemolithotrophs in various habitats such as rice fields [31], Karst caves [29], and marine sediments [32]. More specially, DNA-SIP has been used to identify microorganisms responsible for nitrate-dependent $\mathrm{Fe}(\mathrm{II})$ and $\mathrm{As}$ (III) oxidation [33, 34]. Therefore, DNA-SIP may be capable of identifying nitrate-dependent SbOB as well. Combining DNA-SIP with amplicon and shotgun metagenomics herein, we aimed to (i) investigate the potential of nitratedependent SbO in Sb-contaminated rice paddy soil; (ii) identify bacteria responsible for nitrate-dependent SbO; and (iii) explore the metabolic potentials of the putative nitrate-dependent SbOB.

\section{Methods}

The analyses carried out in this study included chemical characterization of the soil, microcosms incubation, DNA-SIP, and amplicon and shotgun metagenomic sequencings, which are described in detail 
below.

\section{Soil collection and geochemical analyses}

Rice soils were sampled at $30-40 \mathrm{~cm}$ depth from the surface in various flooded rice paddy fields $\left(27^{\circ} 44^{\prime} 38^{\prime \prime} \mathrm{N}, 111^{\circ} 27^{\prime} 46^{\prime \prime} \mathrm{E}\right)$ near Xikuangshan mining area, which were immediately sealed and transported at $4{ }^{\circ} \mathrm{C}$ to the laboratory. In addition, soils from Sb-contaminated arid fields were also collected near the mining area. A preliminary set of experiments were performed to monitor nitratedependent SbO in all of the soils collected from various rice fields and arid fields. The rice paddy soil showing the most rapid rate of nitrate-dependent SbO was selected for further experiments while no soils from arid fields showing nitrate-dependent SbO. The selected rice paddy soil was subsequently subsampled for geochemical analyses and for microcosm setup. The soil contained over $750 \mathrm{mg} \mathrm{kg}^{-1}$ $\mathrm{Sb}, 200 \mathrm{mg} \mathrm{kg}^{-1} \mathrm{As}$, and a $\mathrm{pH}$ of 6.89 (Table S1).

\section{Soil microcosms incubations}

Three sets of microcosms were performed: (i) nitrate-dependent SbO activity incubation - to examine the potential of nitrate-dependent SbO in the rice paddy; (ii) nitrate-dependent SbO enrichment incubation - to monitor the shift in the bacterial community after amending $\mathrm{Sb}$ (III) and $\mathrm{NO}_{3}{ }^{-}$; (iii) SIP incubation - to identify nitrate-dependent SbOB by DNA-SIP.

Nitrate-dependent SbO activity incubation: Soil cultures were prepared by mixing $2 \mathrm{~g}$ of paddy soil and $40 \mathrm{ml}$ of mineral salts medium [53] in serum bottles. The bottles were immediately sealed with aluminium caps and rubber septa after undergoing gas exchange with pure $\mathrm{N}_{2}$ for $20 \mathrm{~min}$. The headspace was then purged with $\mathrm{N}_{2} / \mathrm{CO}_{2}(80 \%: 20 \%, \mathrm{v} / \mathrm{v})$ for $5 \mathrm{~min}$. The redox potential of the cultures was further lowered by adding $60 \mu \mathrm{L}$ sodium sulphide $\left(\mathrm{Na}_{2} \mathrm{~S} \cdot 9 \mathrm{H}_{2} \mathrm{O}, 10 \mathrm{mM}\right)$ solution. $\mathrm{NaHCO}_{3}(8 \mathrm{mM})$ was provided as carbon source in all cultures. Three treatment sets were established with the following amendments: (i) $1 \mathrm{mM}$ $\mathrm{Sb}$ (III) and $3 \mathrm{mM} \mathrm{NO}_{3}{ }^{-} \mathrm{NaNO}_{3}$ ); (ii) $1 \mathrm{mM} \mathrm{Sb}$ (III) only; or (iii) $3 \mathrm{mM} \mathrm{NO}_{3}{ }^{-}$only. Controls inoculated with autoclaved soils were also prepared by providing $1 \mathrm{mM} \mathrm{Sb}(\mathrm{III})$ and $3 \mathrm{mM} \mathrm{NO}_{3}{ }^{-}$. All cultures were incubated at $30^{\circ} \mathrm{C}$ in the dark. Cultures of each treatment were destructively sampled in triplicate after incubation for $0,3,6$, and 12 days. Supernatant collected from each culture was subsampled for analyses of $\mathrm{NO}_{3}{ }^{-}, \mathrm{NO}_{2}{ }^{-}$and $\mathrm{Sb}$ species after immediate centrifugation at $6,000 \mathrm{~g}$ for $15 \mathrm{~min}$. Specifically, $\mathrm{NO}_{3}{ }^{-}$and $\mathrm{NO}_{2}{ }^{-}$concentrations were quantified by a Continuous Flow Analyser (SAN++, Skalar, Holland). $\mathrm{Sb}$ species (i.e., $\mathrm{Sb}(\mathrm{III})$ and $\mathrm{Sb}(\mathrm{V})$ )) were adapted from the methods for measurement of As species using LC-AFS (AFS-920, Haiguang, Beijing) equipped with a hallow cathode lamp for Sb (Shuguangming, Beijing) [54]. The remaining soil sample pellets were subsampled for analyses of Sb species adsorbed in the soil (stored at $4{ }^{\circ} \mathrm{C}$ ) and for molecular microbial community analysis (stored at $-80^{\circ} \mathrm{C}$ ). To extract $\mathrm{Sb}$ species adsorbed in the soil phase, $0.5 \mathrm{~g}$ of the remaining soil sample pellets were mixed with $50 \mathrm{~mL} 1 \mathrm{M}$ $\mathrm{H}_{3} \mathrm{PO}_{4}$ and resuspended by $10 \mathrm{~s}$ ultrasonication, shaken for $2 \mathrm{~h}$ at $200 \mathrm{rpm}$, and followed by $10 \mathrm{~s}$ ultrasonication (modified from a method for As species extraction from soil [55]). The resuspended 
mixture was immediately centrifuged and the resulting supernatant was subject to LC-AFS for Sb species measurement as mentioned above.

Nitrate-dependent SbOB enrichment incubation: To investigate the shift of microbial communities after amending $\mathrm{Sb}(\mathrm{III})$ and $\mathrm{NO}_{3}{ }^{-}$, cultures inoculated with approximately $2 \mathrm{~g}$ paddy soil were prepared, purged and sealed as described above. Two treatments were set up with the following amendments: (i) $1 \mathrm{mM}$ $\mathrm{Sb}$ (III) and $3 \mathrm{mM} \mathrm{NO}_{3}{ }^{-}$; or (ii) $3 \mathrm{mM} \mathrm{NO}_{3}{ }^{-}$only. These cultures were respiked with $8 \mathrm{mM} \mathrm{NaHCO}_{3}, 3 \mathrm{mM}$ $\mathrm{NO}_{3}{ }^{-}$and $1 \mathrm{mM} \mathrm{Sb}$ (III) every 12 days when $\mathrm{Sb}$ (III) was completed oxidized and $\mathrm{NO}_{3}{ }^{-}$was depleted. All the cultures were incubated for a total of 60 days as mentioned above. Triplicate cultures of these two treatments were destructively sampled after incubation for $0,12,30$ and 60 days. Each culture sample was immediately centrifuged and the soil pellet was stored at $-80^{\circ} \mathrm{C}$ for molecular analysis.

SIP incubation: The SIP experiment was established to target putative nitrate-dependent SbOB. Cultures were prepared by amending $2 \mathrm{~g}$ soil inoculum with $40 \mathrm{~mL}$ mineral salts medium [53], and then purged and sealed as described above. Either $8 \mathrm{mM}^{13} \mathrm{C}$ - or ${ }^{12} \mathrm{C}-\mathrm{NaHCO}_{3}$ was supplied as carbon source. Four sets of treatments were performed by amended: (i) $1 \mathrm{mM} \mathrm{Sb}(\mathrm{III}), 3 \mathrm{mM} \mathrm{NO}_{3}{ }^{-}$with either $\mathrm{H}^{13} \mathrm{CO}_{3}{ }^{-}$ (designated as ${ }^{13} \mathrm{CSbN}$ ) or $\mathrm{H}^{12} \mathrm{CO}_{3}$ (designated as ${ }^{12} \mathrm{CSbN}$ ); (ii) $3 \mathrm{mM} \mathrm{NO}_{3}{ }^{-}$with either $\mathrm{H}^{13} \mathrm{CO}_{3}{ }^{-}$ (designated as ${ }^{13} \mathrm{CN}$ ) or $\mathrm{H}^{12} \mathrm{CO}_{3}{ }^{-}$(designated as ${ }^{12} \mathrm{CN}$ ). These cultures were re-spiked every 12 days with $1 \mathrm{mM} \mathrm{Sb}(\mathrm{III}), 3 \mathrm{mM} \mathrm{NO}_{3}{ }^{-}$and either $8 \mathrm{mM}^{13} \mathrm{C}$ - or ${ }^{12} \mathrm{C}-\mathrm{NaHCO}_{3}$. All cultures were incubated as mentioned above, and were destructively sampled in triplicate at day 0,30 and 60 .

\section{DNA extraction and qPCR of aioA and anoA genes}

Genomic DNAs were extracted from soils of three incubations at various time points: nitrate-dependent SbO activity incubation (day 0, 3, 6 and 12, for qPCR), the nitrate-dependent SbOB enrichment incubation (day 0, 12, 30 and 60, for amplicon sequencing), and the SIP incubation (day 0, 30 and 60, for SIP gradient fractionation and amplicon and shotgun metagenomic sequencing). DNA extractions were performed using the DNeasy PowerSoil DNA Kit (QIAGEN, Germany) by following the manufacturer's protocol. The copy numbers of the aioA gene were quantified by qPCR with the primer set aoxBM1-2F (5'CCACTTCTGCATCGTGGGNTGYGGNTA-3')/aoxBM2-1R (5'-GGAGTTGTAGGCGGGCCKRTTRTGDAT-3') by following the protocol published by Quemeneur, et al. [56]. The gene encoding antimonite oxidase (anoA) was enumerated with the primers anoA-F (5'-TCATGGTCGAAAGCATCGG-3')/anoA-R (5'GCGGTTCTGGACGATGTCATA-3') by following the protocol published by Li, et al. [20].

\section{SIP gradient fractionation}

Genomic DNAs from the ${ }^{13} \mathrm{C}$ - and ${ }^{12} \mathrm{C}-\mathrm{NaHCO}_{3}$ SIP incubations (day 0, 30 and 60) were separated into "heavy" (i.e., ${ }^{13} \mathrm{C}$-DNA) and "light" (i.e., ${ }^{12} \mathrm{C}$-DNA) fractions by isopycnic density gradient centrifugation as previous [34]. Briefly, approximately $2 \mu \mathrm{g}$ of genomic DNA was added into $\mathrm{CsCl}$ solution (buoyant density $(B D)=1.714 \mathrm{~g} \mathrm{~mL}^{-1}$ ) in an OptiSeal polyallomer tube (Beckman Coulter, Palo Alto, USA). The mixture was 
then ultracentrifuged at 409,000 $\mathrm{g}$ for $24 \mathrm{~h}$ using a VTi 90 vertical rotor in an Optima XPN-100 Ultracentrifuge (Beckman Coulter). The resulting $\mathrm{CsCl}$ gradients were then fractionated into 24 equal volumes $(\sim 200 \mu \mathrm{L})$ with a fraction recovery system (Beckman Coulter, USA) [57, 58]. The BD value of each fraction was immediately determined by measuring the refractive index using a digital refractometer (Palette, ATAGO, Japan). DNA in each fraction were precipitated with $6 \mu \mathrm{L}$ glycogen (ZOMANBIO, China) dissolved in $30 \%$ cold ethanol and then finally eluted in $30 \mu \mathrm{L}$ of TE buffer $(\mathrm{pH} 8.0)[57,58]$. From the eluted DNA, qPCR was used as described above to determine the copy numbers of aioA gene in each of the 24 fractions collected.

\section{Illumina Miseq sequencing and analysis}

Genomic DNAs from the nitrate-dependent SbOB enrichment incubations (day 0, 12, 30 and 60) were subject to amplicon sequencing of the partial 16S rRNA gene with the primers $520 f\left(5^{\prime}\right.$ -

AYTGGGYDTAAAGNG-3')/802r(5'-TACNVGGGTATCTAATCC-3') [59]. In addition, three representative heavy or light fractions containing the highest aioA gene abundance from each culture of the ${ }^{13} \mathrm{CSbN}(\mathrm{H} 1-\mathrm{H} 3)$,

${ }^{12} \mathrm{CSbN}(\mathrm{L} 1-\mathrm{L} 3)$ and ${ }^{13} \mathrm{CN}(\mathrm{H} 1-\mathrm{H} 3)$ treatments (day 60) were pooled as composite DNA samples

respectively, and then the nine composite DNA samples (one composite DNA sample per culture, triplicate cultures per treatment) were sequenced for the partial $16 \mathrm{~S}$ rRNA gene with the primer set $520 \mathrm{f} / 802 \mathrm{r}$. The amplicon sequencing was performed on an Illumina MiSeq platform (Personalbio, Shanghai, China) [60]. Approximately $22.9 \mathrm{Mb}$ raw paired-end reads per culture were generated and then analysed with the QIIME2-201904 toolkit [61]. Briefly, all the raw reads were qualified, merged and Chimera-removed (-ptrim-left-f 0, -p-trim-left-r 228, -p-trunc-len-f 0, -p-trunc-len-r 219). The filtered reads (approximately $21.9 \mathrm{Mb}$ per culture) were then clustered into amplicon sequence variants (ASV) with DADA2 [62]. The obtained ASV features (>0.01\%) were assigned into taxonomy against the SILVA database [63].

\section{Shotgun metagenomic sequencing and analysis}

The heavy DNA fractions with the highest aioA gene abundance from triplicate cultures of ${ }^{13} \mathrm{CSbN}$ (i.e., $\mathrm{H} 2$ from triplicate microcosms of ${ }^{13} \mathrm{CSbN}$ at day 60 ) were pooled as one composite DNA sample, which was sequenced for the metagenome on an Illumina Hiseq 4000 platform (Personalbio, Shanghai, China). All the raw reads $(17.9 \mathrm{~Gb}$ ) were trimmed and qualified using Trimmomatic 0.36 (SLIDINGWINDOW:4:20 MINLEN:70) [64]. The qualified reads (17.1 Gb) were assembled into contigs using Megahit $(k=21-121$, step $=10$ ) [65] and then taxonomically assigned by comparing against the NCBI database using Kraken2 with default settings [66]. Subsequently, binning of the obtained contigs was performed and further refined using MaxBIN2 (default settings) [67] and metaBAT2 (default settings) [68] integrated in MetaWRAP [67]. Contamination and completion of all bins were determined by CheckM [69]. Only highquality bins with completion $>70 \%$ and contamination $<5 \%$ were selected for further analyses. Taxonomy of the bins was classified using Taxator-tk (default settings) [70]. Annotation of the bins was performed using KofamKOALA online (score > 60, evalue = 1e-5) (https://www.genome.jp/tools/kofamkoala/) [71]. In addition, the bins phylogenetic tree was generated based on conserved protein sequences with PhyloPhIAn [72]. 


\section{Results}

\section{Activity of nitrate-dependent SbO}

Oxidation of $\mathrm{Sb}(\mathrm{III})$ to $\mathrm{Sb}(\mathrm{V})$ was only observed in the treatment amended with both $\mathrm{Sb}(\mathrm{III})$ and $\mathrm{NO}_{3}{ }^{-}$but not in the treatment amended with $\mathrm{Sb}(\mathrm{III})$ or $\mathrm{NO}_{3}{ }^{-}$only (Fig. 1a and b). Approximately $0.90 \pm 0.08 \mathrm{mM}$ $\mathrm{Sb}(\mathrm{III})$ was fully oxidized to $\mathrm{Sb}(\mathrm{V})(0.87 \pm 0.04 \mathrm{mM})$ after an incubation period of 12 days, with $2.26 \pm$ $0.06 \mathrm{mM} \mathrm{NO}_{3}{ }^{-}$reduced. In contrast, $0.11 \pm 0.00 \mathrm{mM} \mathrm{Sb}(\mathrm{V})$ (probable carryover from the paddy soil) was detected at day 0 in the treatments amended with $\mathrm{Sb}$ (III) only, but no discernable SbO was detected over the course of incubation (Fig. 1a and b). Nitrate reduction $(1.41 \pm 0.03 \mathrm{mM}$ ) was also observed in the treatment amended with $\mathrm{NO}_{3}{ }^{-}$only, but was significantly less than that in the treatment amended with both $\mathrm{Sb}(\mathrm{III})$ and $\mathrm{NO}_{3}{ }^{-}(P<0.05)$ (Fig. 1c). These observations suggest that anaerobic $\mathrm{SbO}$ in these cultures was nitrate-dependent. In addition, neither $\mathrm{SbO}$ nor $\mathrm{NO}_{3}{ }^{-}$reduction was detected in the sterile controls inoculated with autoclaved soil (Fig. 1), indicating that anaerobic SbO was mainly driven by microorganisms in the paddy soil.

\section{Increase in the abundance of the aioA gene over the course of nitrate-dependent SbO}

Given that arsenite oxidase AioA has been reported to catalyze SbO in previous studies [20, 35], the aioA gene was quantified in all treatments from nitrate-dependent SbO activity incubations at day 0, 3, 6 and 12. The copies of the aioA gene significantly increased by 1.4-fold throughout the 12-day incubation in the treatments amended with $\mathrm{Sb}(\mathrm{III})$ and $\mathrm{NO}_{3}{ }^{-}(P<0.05)$, while no such change in aioA genes was observed in the treatments amended with Sb only (Fig. 2a). A significant decrease in the abundance of the aio $A$ gene was observed in the treatments amended with $\mathrm{NO}_{3}{ }^{-}$only $(P<0.05)$ (Fig. 2a), suggesting that aioA gene-containing microorganisms might be outcompeted by others when no stress of $\mathrm{Sb}$ contamination occurred. In addition, a significantly positive correlation between the copies of the aio $A$ gene and concentrations of $\mathrm{Sb}(\mathrm{V})$ was found in the treatment amended with $\mathrm{Sb}(\mathrm{III})$ and $\mathrm{NO}_{3}{ }^{-}(\mathrm{R}=0.88, P$ <0.05) (Fig. 2b), while no such correlations were found in treatments amended with $\mathrm{Sb}$ or $\mathrm{NO}_{3}{ }^{-}$only (data not shown). No PCR products were obtained by amplifying genes encoding antimonite oxidase (ano $A$ ) in any of these three treatments (data not shown).

\section{Shift of bacterial communities over the course of nitrate- dependent SbO}

The bacterial communities of two treatments (treatment amended with $\mathrm{Sb}(\mathrm{III})$ and $\mathrm{NO}_{3}{ }^{-}$and treatment amended with $\mathrm{NO}_{3}{ }^{-}$only) were further characterized. Accordingly, an obvious shift in the bacterial 
communities was detected in the treatment amended with $\mathrm{Sb}(\mathrm{III})$ and $\mathrm{NO}_{3}{ }^{-}$over the course of the incubation (day 0, 12, 30 and 60) (Fig. 3). Specifically, the relative abundance of Azoarcus significantly increased from undetectable at day 0 to $78 \pm 2 \%$ at day 60 in treatments amended with $\mathrm{Sb}$ (III) and $\mathrm{NO}_{3}{ }^{-}$ $(P<0.05)$ (Fig. 3). The proportion of bacteria associated with Azospira reached their peak $(42 \pm 6 \%)$ at day 30 then decreased to $5 \pm 2 \%$ at day 60 in treatments amended with $\mathrm{Sb}$ (III) and $\mathrm{NO}_{3}{ }^{-}(P<0.05)$ (Fig. 3). In contrast, bacterial communities were relatively stable in treatments amended with $\mathrm{NO}_{3}{ }^{-}$only, with Herbaspirillum and Gemmatimonas gradually increasing from undetectable at day 0 to $10 \pm 2 \%$ at day 60 and from $4 \pm 0 \%$ at day 0 to $9 \pm 1 \%$ at day 60 , respectively (Fig. 3). Further, PERMANOVA demonstrated that the bacterial communities were significantly different between the treatment amended with $\mathrm{Sb}$ (III) and $\mathrm{NO}_{3}{ }^{-}$and the treatment amended with $\mathrm{NO}_{3}{ }^{-}$only $(P=0.001)$, suggesting that $\mathrm{Sb}(\mathrm{III})$ plus $\mathrm{NO}_{3}{ }^{-}$ shapes the bacterial communities and possibly enriched those involved in nitrate-dependent SbO. Therefore, DNA-SIP combined with amplicon sequencing was subsequently performed to identify the microorganisms responsible for nitrate-dependent SbO.

\section{SbOB identified by DNA-SIP and amplicon sequencing of 16S rRNA gene}

The maximum abundance of aio $A$ gene was detected in the light fraction $\left(\mathrm{BD}=1.708 \mathrm{~g} \mathrm{ml}^{-1}\right)$ of ${ }^{12} \mathrm{CSbN}$ during the SIP incubation (Fig. 4). Compared to ${ }^{12} \mathrm{CSbN}$, the highest abundance of the aio $A$ gene gradually shifted to the heavier fractions $\left(B D=1.712\right.$ at day $30, B D=1.727 \mathrm{~g} \mathrm{ml}^{-1}$ at day 60$)$ in the ${ }^{13} \mathrm{CSbN}$ treatment only (Fig. 4), implying that nitrate-dependent SbOB incorporated ${ }^{13} \mathrm{C}$ over the course of the incubation. In contrast, no obvious shifts in abundance of the aioA gene to the heavy fractions were detected in ${ }^{12} \mathrm{CSbN},{ }^{12} \mathrm{CN}$ or ${ }^{13} \mathrm{CN}$ treatments (Fig. 4).

Fractions containing the highest abundances of aioA genes from each culture of the treatments ${ }^{13} \mathrm{CSbN}$ (H1-H3, Fig. 4), ${ }^{12} \mathrm{CSbN}$ (L1-L3, Fig. 4), and ${ }^{13} \mathrm{CN}(\mathrm{H} 1-\mathrm{H} 3$, Fig. 4) at day 60 were pooled as composite DNA samples and were then subject to $16 \mathrm{~S}$ rRNA amplicon sequencing. As shown in Fig. 5a, bacteria affiliated with Azoarcus ( $45 \pm 6 \%$ ) dominated the heavy DNA fractions in the ${ }^{13} \mathrm{CSbN}$ treatment, followed by Gemmatimonas (18 $\pm 4 \%$ ), Ramlibacter ( $5 \pm 0 \%)$, Halomonas ( $4 \pm 1 \%$ ) and Chelativorans ( $2 \pm 0 \%)$. Notably, Gemmatimonas $\left(9 \pm 2 \%\right.$ ) was also the most abundant genus in the heavy fractions of the ${ }^{13} \mathrm{CN}$ treatment (Fig. 5a), implying that they were more likely autotrophic denitrifiers without the capability to oxidize $\mathrm{Sb}$ (III). In addition, linear discriminant analysis effect size (LEfSe) analysis identified 19 genera that showed significantly different abundances in the heavy DNA fractions between the ${ }^{13} \mathrm{CSbN}$ and ${ }^{13} \mathrm{CN}$ treatments ( $P<0.05$ and LDA score $>2.0)$ (Fig. 5b). Specifically, Azoarcus, Halomonas, Geobacter, Azospira, Pelagibacterium and Chelativorans were significantly enriched in the heavy fractions of the ${ }^{13} \mathrm{CSbN}$ treatment, implying that bacteria associated with these six genera might play a role in nitratedependent SbO. Their exact role was further examined by metagenomic-binning to detect the presence of some key genes for nitrate-dependent SbO in bins associated with these bacteria. 


\section{Shotgun metagenomic analysis of the heavy fractions from ${ }^{13} \mathrm{CSbN}$ treatment}

Taxonomic assignment of the metagenome from the heavy DNA fractions in the ${ }^{13} \mathrm{CSbN}$ treatment revealed that Azoarcus (42\%) was the most dominant genus, followed by Thauera (6\%), Streptomyces (2\%), Pseudomonas (2\%), Burkholderia (2\%) and Ramlibacter (2\%) (Fig. S1). Further, metagenomicbinning was performed. Assembled bins were affiliated with Proteobacteria, Gemmatimonadetes and Verrucomicrobia (Fig. S2). Bins associated with putative nitrate-dependent SbOB identified by the abovementioned SIP experiments, such as Azoarcus sp. (bin9), Azospira sp. (bin10) and Chelativorans sp. (bin14), were obtained (Fig. S2), whereas bins associated with Halomonas, Geobacter, and Pelagibacterium were not obtained. Also, bins associated with the genera showing relatively higher abundance in the metagenome were obtained, including Thauera (bin4) and Ramlibacter(bin3) (Fig. S2). Genetic annotations of these bins showed that most of the bins (except for Devosia-associated bin6, and Gemmatimons-associated bin8 and bin15) harboured aioA genes, while aioB genes were observed in only three bins (Thauera-associated bin4, Vulgatibacteraceaeassociated bin12, and Chelativorans-associated bin14) (Fig. 6). Genes involved in denitrification, including those responsible for $\mathrm{NO}_{3}{ }^{-}-, \mathrm{NO}_{2}{ }^{-}$, $\mathrm{NO}$ - and $\mathrm{N}_{2} \mathrm{O}$-reduction, were investigated. Generally, nitrate-reducing genes were the most abundant genes detected in all bins, followed by $\mathrm{NO}_{2}{ }^{-}$-reducing and NO-reducing genes (Fig. 6). Among them, Ramlibacter-associated bin3, Azoarcus-associated bin9, Azospira-associated bin10 and Anaeromyxobacter-associated bin13 were observed to encompass the genes driven the whole denitrification process from $\mathrm{NO}_{3}{ }^{-}$to $\mathrm{N}_{2}$. In addition, all of the bins contained a number of genes involved in carbon fixation, suggesting their capability of autotrophic growth (Fig. 6).

\section{Discussion}

Rice has been suggested as a major route for $\mathrm{Sb}$ exposure, especially in mining areas $[14,36]$, and is reported to be more efficient in taking up $\mathrm{Sb}(\mathrm{III})$ than $\mathrm{Sb}(\mathrm{V})$ [14]. SbO will generate the less mobile $\mathrm{Sb}(\mathrm{V})$ and thus reduce the uptake of $\mathrm{Sb}$ by the rice. Therefore, $\mathrm{SbO}$ may be beneficial to attenuate the consequences Sb contamination in rice paddies. The anoxic conditions and the high levels of nitrate in rice paddies may facilitate nitrate-dependent $\mathrm{SbO}$, which, however, has never been reported in rice paddies. Therefore, the current study tackles this important but less understood environmental issue to investigate the potential of nitrate-dependent $\mathrm{SbO}$ in the Sb-contaminated rice paddies.

Our current understanding of anaerobic $\mathrm{Sb}$ (III) oxidizers is mainly based on three isolates $[13,18,27]$. Culture-independent tools such as DNA-SIP may be available to expand the list of nitrate-dependent SbOB. However, clear Sb-dependent growth is difficult to observe because SbOB require high concentrations (millimolar range) of $\mathrm{Sb}$ (III) to prompt significant increases in biomass [26]. The slow growing nature of $\mathrm{SbOB}$ may increase the required duration of ${ }^{13} \mathrm{C}$ incorporation and thus incur crossfeeding, which complicates the interpretation of SIP data. The current study aims to examine the proof of 
concept of using DNA-SIP combined with 16S rRNA gene amplicon sequencing to reveal nitratedependent SbOB. Given that the long incubation time for DNA-SIP may cause cross-feeding among microorganisms, shotgun metagenomic sequencing was further performed on the heavy DNA fractions of ${ }^{13} \mathrm{CSbN}$ to examine whether some key genes responsible for nitrate-dependent $\mathrm{SbO}$ (i.e., $\mathrm{Sb}$ (III) oxidation, nitrate reduction, and carbon fixation) were present in the putative nitrate-dependent SbOB to confirm their role in nitrate-dependent SbO.

\section{Nitrate-dependent SbO potential of the Sb-contaminated rice paddy soil}

Anaerobic $\mathrm{Sb}(\mathrm{III})$ oxidation to $\mathrm{Sb}(\mathrm{V})$ was clearly demonstrated in the anoxic rice-paddy cultures amended with $\mathrm{Sb}$ (III) and $\mathrm{NO}_{3}{ }^{-}$, but not in the cultures amended with $\mathrm{NO}_{3}{ }^{-}$or $\mathrm{Sb}$ (III) only (Fig. 1), suggesting that the addition of nitrate may facilitate SbO. Nitrate reduction with concomitant $\mathrm{SbO}$ is further supported by the conversion of nitrate to nitrite (Fig. $1 \mathrm{c}$ and d). Sterile controls showed no formation of $\mathrm{Sb}(\mathrm{V})$ supporting that nitrate-dependent $\mathrm{SbO}$ is a biotic process. Overall, this observation confirms that bacteria can mediate nitrate-dependent $\mathrm{SbO}$ in rice paddy soils.

\section{aioA may be the key gene for nitrate-dependent SbO}

Given similar chemical properties shared by $\mathrm{Sb}$ and As elements, it has been proposed that microbes may drive $\mathrm{Sb}$ transformation by using similar metabolic pathways with As. Previous studies suggest that arsenite oxidase (encoded by the aioA gene) may be responsible for SbO. For example, the aioA gene has been detected in some known nitrate-dependent SbOB including Hydrogenophaga taeniospiralis strain IDSBO-1 and Sinorhizobium sp. GW3 [13, 27]. In addition, the transcription level of the aioA gene in Sb(III)oxidizing Sinorhizobium sp. GW3 significantly increased upon $\mathrm{Sb}$ (III) addition under anaerobic conditions and a mutation in the aioA gene reduced the anaerobic SbO rate by over $70 \%$ [13]. Consistently, several observations in this study also support that the aioA gene is involved in anaerobic SbO: (i) the copy numbers of the aioA gene increased only in the cultures with nitrate-dependent SbO (Fig. 2a). The abundance of the aioA gene showed significant positive correlations with the concentration of $\mathrm{Sb}(\mathrm{V})$ produced over the course of nitrate-dependent $\mathrm{SbO}$ in the treatment amended with both $\mathrm{Sb}(\mathrm{III}) \mathrm{and}^{-} \mathrm{NO}_{3}{ }^{-}$ $(\mathrm{R}=0.88, P<0.05)$ (Fig. 2b), whereas such correlation was not detected in two other treatments where nitrate-dependent SbO was not observed (data not shown); (ii) following a 60-day incubation period, the highest relative abundance of the aioA gene was observed to gradually shift to the heavier DNA fractions only in the ${ }^{13} \mathrm{CSbN}$ treatment where nitrate-dependent $\mathrm{SbO}$ occurred, while no obvious shifts to the heavier fractions were found in other treatments (i.e., ${ }^{13} \mathrm{CSbN},{ }^{13} \mathrm{CN}$ and ${ }^{12} \mathrm{CN}$ ). These observations collectively support that the aioA gene is responsible for nitrate-dependent $\mathrm{SbO}$. A Sb(III) oxidase, encoded by anoA gene, belonging to the short-chain dehydrogenase/reductase family was recently identified and proposed to be responsible for aerobic SbO [20]. In this study, the anoA gene, however, was 
neither successfully amplified from any of the treatments nor observed in the metagenome, implying that anoA may not be responsible for nitrate-dependent $\mathrm{SbO}$ in this rice paddy soil.

\section{Putative nitrate-dependent SbOB identified by DNA-SIP}

A number of genera, such as Azoarcus, Azospira and Chelativorans, were proposed as putative nitratedependent $\mathrm{SbOB}$ in the current study. The relative abundance of Azoarcus spp. increased from undetectable in the original rice paddy soil inoculum to $78 \%$ at day 60 in the cultures amended with $\mathrm{Sb}$ (III) and $\mathrm{NO}_{3}{ }^{-}$(Fig. 3). Since Azoarcus was not enriched in the cultures amended with $\mathrm{NO}_{3}{ }^{-}$only, it suggests that SbO likely supported its growth. Furthermore, as seen in the DNA-SIP result (Fig. 5), Azoarcus dominated (close to $50 \%$ ) in the heavy DNA fractions of the ${ }^{13} \mathrm{CSbN}$ treatment, but was not found in the ${ }^{13} \mathrm{CN}$ treatments, thus demonstrating that Azoarcus incorporated ${ }^{13} \mathrm{C}-\mathrm{NaHCO}_{3}$ only during nitratedependent SbO. Azoarcus spp. are well known for their capability to mediate nitrate-dependent As(III) oxidation via AioA in paddy soils and other environments [34,38]. Consistently, aioA genes were observed in the bin associated with Azoarcus (bin9), supporting their role also in SbO. In addition, genes for denitrification and carbon fixation were observed in the Azoarcus-associated bin9, suggesting its capability for denitrification and autotrophy (Fig. 6). Collectively, these results support that Azoarcusassociated bacteria are responsible for the autotrophic oxidation of $\mathrm{Sb}$ (III) linked to nitrate reduction in the paddy soil. Bacteria associated with Azospira dominated ( $42 \pm 6 \%)$ the bacterial communities in the treatment amended with $\mathrm{Sb}(\mathrm{III})$ and $\mathrm{NO}_{3}{ }^{-}$at day 30 (Fig. 3) and was observed to be significantly enriched in the heavy DNA fractions of ${ }^{13} \mathrm{CSbN}$ treatment compared to ${ }^{13} \mathrm{CN}$ (Fig. 5). In addition, a bin associated with Azospira containing the aioA gene was detected in the ${ }^{13} \mathrm{C}$-heavy-fraction metagenome (Fig. 6). These observations suggest that Azospira may be a putative nitrate-dependent SbOB. The detection of genes for denitrification and carbon fixation in the Azospira-associated bin also supported its capability for nitrate-dependent SbO. Nitrogen cycling by the genus Azospira has been previously described, including nitrogen fixation and denitrification $[39,40]$. Although Azospira spp. has not previously been shown to oxidize $\mathrm{Sb}$ (III) under either aerobic or denitrifying conditions, autotrophic Azospira sp. strain ECC1-pb2 isolated from sludge and sediment samples was capable of As(III) oxidation linked to chlorate reduction [41]. Our current study identified Azospira spp. as putative nitrate-dependent SbOB.

Chelativorans-affiliated bacteria were identified as putative nitrate-dependent SbOB in this study because of two reasons: (i) they were significantly enriched in the heavy fractions of ${ }^{13} \mathrm{CSbN}$ than their counterparts in ${ }^{13} \mathrm{CN}$ (Fig. 5); (ii) aio $A B$ genes and denitrifying genes were observed in the Chelativoransassociated bin (Fig. 6), supporting their potential ability for nitrate-dependent SbO. Members of Chelativorans have been extensively identified as heterotrophic denitrifiers and have been enriched in uranium-contaminated soil [42-44]. However, the detection of genes for carbon fixation suggested that they hole the potential to oxidize $\mathrm{Sb}(\mathrm{III})$ autotrophically.

Metagenomic-binning of the ${ }^{13} \mathrm{C}$-heavy-fraction metagenome provides an additional method to examine the physiological traits of the nitrate-dependent SbOB community. Many bins, such as those associated 
with Thauera, Ramlibacter and Anaeromyxobacter, contained an aioA gene. Although Thauera, Ramlibacter and Anaeromyxobacter have been detected in As-contaminated sites previously [45-47], their role in either $\mathrm{As}(\mathrm{III})$ or $\mathrm{Sb}(\mathrm{III})$ oxidation has not been reported. The presence of aioA and the genes responsible for denitrification and carbon fixation in the bins related with these genera (Fig. 6), suggests that they have the potential for nitrate-dependent SbO.

Relatively higher abundance of Gemmatimonas was observed in the heavy DNA fractions of both ${ }^{13} \mathrm{CSbN}$ and ${ }^{13} \mathrm{CN}$ than those in corresponding light fractions. Neither aioA nor aioB, however, was detected while genes involved in denitrification and carbon fixation were observed in the Gemmatimonas-associated bins (bin8). These observations suggested that Gemmatimonas may be more likely autotrophic denitrifier without the capability to oxidize $\mathrm{Sb}(\mathrm{III})$. In addition, bacteria associated with Halomonas, Geobacter and Pelagibacterium were significantly enriched in the heavy fractions in the ${ }^{13} \mathrm{CSbN}$ treatment than that of ${ }^{13} \mathrm{CN}$ (Fig. 5). Although Halomonas was identified as As(III) oxidizers [48], Geobacter spp. are notable for their capability for metal reduction [49] and Pelagibacterium has never been associated with As or Sb transformation. Unfortunately, bins associated with these three genera were not detected by the metagenomic-binning, thus we cannot determine whether they are potentially nitrate-dependent SbOB. Further investigation, such as isolation of members of these genera, are necessary to reveal their role in nitrate-dependent SbO.

The current study provided a proof of concept of using DNA-SIP to identify nitrate-dependent SbOB. The long incubation time (60 day) are necessary to observe obvious shift of ${ }^{13} \mathrm{C}$-incorporating microbial communities. Because long incubation time may incur cross-feeding [50], shotgun metagenomics followed by DNA-SIP is suggested to provide the physiological traits of the putative nitrate-dependent $\mathrm{SbOB}$ and identify the scavenging denitrifies or other microorganisms incorporating ${ }^{13} \mathrm{C}$ from crossfeeding.

\section{Conclusions}

Rice is a staple food in China and is a major route (over $30 \%$ of the daily intake) for Sb exposure in some $\mathrm{Sb}$ mining areas [8], especially when rice is grown close to $\mathrm{Sb}$ mines. Since $\mathrm{Sb}$ (III) is more efficiently taken up by rice than $\mathrm{Sb}(\mathrm{V})[8,14]$, oxidation of $\mathrm{Sb}(\mathrm{III})$ in the rice paddies can have health and environmental benefits by reducing the uptake of $\mathrm{Sb}$ by rice. The current study showed that: (i) nitrate-dependent $\mathrm{SbO}$ can take place and carried out by the innate microbiota in rice paddy soils; (ii) the aioA gene may be the key gene responsible for nitrate-dependent SbO; (iii) a number of novel putative nitrate-dependent SbOB including bacteria associated with the genera Azoarcus, Azospira, and Chelativorans were identified by DNA-SIP.

\section{Declarations}

\section{Ethics approval and consent to participate}




\section{Consent for publication}

Not applicable

\section{Availability of data and materials}

The nucleotide sequences generated by amplicon and shotgun metagenome sequencing in this study have been deposited in GenBank database (Bioproject: PRJNA640466).

\section{Competing interests}

The authors declare that they have no competing interests.

\section{Funding}

This research was financially supported by the National Natural Science Foundation of China (grant nos. 41907285 and 41771301), GDAS' Project of Science and Technology Development (grant nos. 2019GDASYL-0103053, 2019GDASYL-0301002, 2019GDASYL-0103047, 2019GDASYL-0103046, 2020GDASYL-20200103086 and 2020GDASYL-20200402003), Science and Technology Planning Project of Guangzhou (grant no. 202002020072), Guangdong Foundation for Program of Science and Technology Research (grant no. 2019B121205006), Local Innovative and Research Teams Project of Guangdong Pearl River Talents Program (grant no. 2017BT01Z176), High-level Leading Talent Introduction Program of GDAS (grant no. 2016GDASRC-0103), and Guangdong Introducing Innovative and Entrepreneurial Talents (2017GC010570).

\section{Authors' contributions}

M.Z. is the main author of this paper. M.Z. and L.Z. performed all the incubation experiments, DNA extraction, PCR experiments, and sequencings. Z.H. and Q.L. performed the chemical analysis. M.Z., Z.H., and G.L. performed SIP gradient fractionation. X.S. and R.X. helped interpret the data. M.Z. wrote the manuscript, and M.M.H., L.Y., F.L., and W.S. revised the manuscript. This project was conceived and designed by M.Z. and W.S. All authors have read, revised, and approved the manuscript.

\section{Acknowledgements}

We would like to thank Mr. Xin Ye and Mr. Jiatai Xiong for assistance in soil collection. 


\section{References}

1. Wilson SC, Lockwood PV, Ashley PM, Tighe M. The chemistry and behaviour of antimony in the soil environment with comparisons to arsenic: a critical review. Environ Pollut. 2010;158:1169-81.

2. Gebel T. Arsenic and antimony comparative approach on mechanistic toxicology. Chem-Biol Interact. 1997;107:131-44.

3. Sundar S, Chakravarty J. Antimony toxicity. Int J Env Res Pub He. 2010;7:4267-77.

4. Filella M, Belzile N, Chen Y-W. Antimony in the environment: a review focused on natural waters I. Occurrence. Earth-Sci Rev. 2002;57:125-76.

5. Telford K, Maher W, Krikowa F, Foster S, Ellwood MJ, Ashley PM, et al. Bioaccumulation of antimony and arsenic in a highly contaminated stream adjacent to the Hillgrove Mine, NSW, Australia. Environ Chem 2009;6.

6. Wilson NJ, Craw D, Hunter K. Contributions of discharges from a historic antimony mine to metalloid content of river waters, Marlborough, New Zealand. J Geochem Explor. 2004;84:127-39.

7. Wen B, Zhou J, Zhou A, Liu C, Xie L. Sources, migration and transformation of antimony contamination in the water environment of Xikuangshan, China: Evidence from geochemical and stable isotope (S, Sr) signatures. Sci Total Environ 2016;569-570:114 - 22.

8. 25. Wu F, Fu Z, Liu B, Mo C, Chen B, Corns W, et al. Health risk associated with dietary co-exposure to high levels of antimony and arsenic in the world's largest antimony mine area. Sci Total Environ 2011;409:3344-51.

9. Filellaa M, Belzileb N, Chen Y. Antimony in the environment: a review focused on natural waters II. Relevant solution chemistry. Earth-Sci Rev. 2002;59:265-85.

10. Hockmann K, Lenz M, Tandy S, Nachtegaal M, Janousch M, Schulin R. Release of antimony from contaminated soil induced by redox changes. J Hazard Mater. 2014;275:215-21.

11. Leuz A-K, Mönch $\mathrm{H}$, Johnson CA. Sorption of $\mathrm{Sb}$ (III) and $\mathrm{Sb}(\mathrm{V})$ to goethite influence on $\mathrm{Sb}$ (III) oxidation and mobilization. Environ Sci Technol. 2006;40:7277-82.

12. Tschan M, Robinson B, Johnson CA, Bürgi A, Schulin R. Antimony uptake and toxicity in sunflower and maize growing in $\mathrm{Sb}^{\mathrm{III}}$ and $\mathrm{Sb}^{\mathrm{V}}$ contaminated soil. Plant Soil. 2010;334:235-45.

13. Li J, Zhang Y, Zheng S, Liu F, Wang G. Anaerobic bacterial immobilization and removal of toxic Sb(III) coupled with $\mathrm{Fe}(\mathrm{II}) / \mathrm{Sb}$ (III) oxidation and denitrification. Front Microbiol. 2019;10:360.

14. 26. Ren JH, Ma LQ, Sun HJ, Cai F, Luo J. Antimony uptake, translocation and speciation in rice plants exposed to antimonite and antimonate. Sci Total Environ 2014;475:83-9.

15. Lehr CR, Kashyap DR, McDermott TR. New insights into microbial oxidation of antimony and arsenic. Appl Environ Microbiol. 2007;73:2386-9.

16. Oremland RS, Stolz JF. The ecology of arsenic. Science. 2003;300:939-44.

17. Stolz JF, Basu P, Santini JM, Oremland RS. Arsenic and selenium in microbial metabolism. Annu Rev Microbiol. 2006;60:107-30. 
18. Nguyen VK, Choi W, Yu J, Lee T. Microbial oxidation of antimonite and arsenite by bacteria isolated from antimony-contaminated soils. Int J Hydrogen Energ. 2017;42:27832-42.

19. Hu A, Ju F, Hou L, Li J, Yang X, Wang H, et al. Strong impact of anthropogenic contamination on the co-occurrence patterns of a riverine microbial community. Environ Microbiol. 2017;19:4993-5009.

20. Li J, Wang Q, Li M, Yang B, Shi M, Guo W, et al. Proteomics and genetics for identification of a bacterial antimonite oxidase in Agrobacterium tumefaciens. Environ Sci Technol. 2015;49:5980-9.

21. Gurnani N, Sharma A, Tulukder G. Effects of antimony on cellular systems in animals: a review. Nucleus. 1994;37:71-96.

22. Nguyen VK, Lee J-U. Antimony-oxidizing bacteria isolated from antimony-contaminated sediment - a phylogenetic study. Geomicrobiol J. 2014;32:50-8.

23. Li J, Wang Q, Zhang S, Qin D, Wang G. Phylogenetic and genome analyses of antimony-oxidizing bacteria isolated from antimony mined soil. Inter Biodeter Biodegr. 2013;76:76-80.

24. Hamamura N, Fukushima K, Itai T. Identification of antimony- and arsenic-oxidizing bacteria associated with antimony mine tailing. Microbes Environ. 2013;28:257-63.

25. Lialikova NN. Stibiobacter senarmontii-a new microorganism oxidizing antimony. Mikrobiologiia. 1974;43:941-8.

26. Tang J, Liao Y, Yang Z, Chai L, Yang W. Characterization of arsenic serious-contaminated soils from Shimen realgar mine area, the Asian largest realgar deposit in China. J Soils Sediments. 2016;16:1519-28.

27. Terry LR, Kulp TR, Wiatrowski H, Miller LG, Oremland RS. Microbiological oxidation of antimony(III) with oxygen or nitrate by bacteria isolated from contaminated mine sediments. Appl Environ Microbiol. 2015;81:8478-88.

28. Wang X, He M, Xi J, Lu X. Antimony distribution and mobility in rivers around the world's largest antimony mine of Xikuangshan, Hunan Province, China. Microchem J. 2011;97:4-11.

29. Wang N, Zhang S, He M. Bacterial community profile of contaminated soils in a typical antimony mining site. Environ Sci Pollut Res Int. 2018;25:141-52.

30. Radajewski S, Ineson P, Parekh NR, Murrell JC. Stable-isotope probing as a tool in microbial ecology. Nature. 2000;403:646-9.

31. Liu F, Conrad R. Chemolithotrophic acetogenic $\mathrm{H}_{2} / \mathrm{CO}_{2}$ utilization in Italian rice field soil. The ISME Journal. 2011;5:1526-39.

32. Fortunato CS, Huber JA. Coupled RNA-SIP and metatranscriptomics of active chemolithoautotrophic communities at a deep-sea hydrothermal vent. The ISME Journal. 2016;10:1925-38.

33. Kanaparthi D, Pommerenke B, Casper P, Dumont MG. Chemolithotrophic nitrate-dependent Fe(II)oxidizing nature of actinobacterial subdivision lineage TM3. The ISME Journal. 2013;7:1582-94.

34. Zhang M, Li Z, Haggblom MM, Young L, He Z, Li F, et al. Characterization of nitrate-dependent As(III)oxidizing communities in arsenic-contaminated soil and investigation of their metabolic potentials 
by the combination of DNA-stable isotope probing and metagenomics. Environ Sci Technol. 2020;54:7366-77.

35. Wang Q, Warelow TP, Kang YS, Romano C, Osborne TH, Lehr CR, et al. Arsenite oxidase also functions as an antimonite oxidase. Appl Environ Microbiol. 2015;81:1959-65.

36. Cai F, Ren J, Tao S, Wang X. Uptake, translocation and transformation of antimony in rice (Oryza sativa L.) seedlings. Environ Pollut. 2016;209:169-76.

37. Oremland RS, Hoeft SE, Santini JM, Bano N, Hollibaugh RA, Hollibaugh JT. Anaerobic oxidation of arsenite in Mono Lake water and by a facultative, arsenite-oxidizing chemoautotroph, strain MLHE-1. Appl Environ Microbiol. 2002;68:4795-802.

38. Rhine ED, Phelps CD, Young LY. Anaerobic arsenite oxidation by novel denitrifying isolates. Environ Microbiol. 2006;8:899-908.

39. Bae HS, Rash BA, Rainey FA, Nobre MF, Tiago I, da Costa MS, et al. Description of Azospira restricta sp. nov., a nitrogen-fixing bacterium isolated from groundwater. Int J Syst Evol Micr. 2007;57:15216.

40. Rossi F, Motta O, Matrella S, Proto A, Vigliotta G. Nitrate removal from wastewater through biological denitrification with OGA 24 in a batch reactor. Water. 2014;7:51-62.

41. Sun W, Sierra-Alvarez R, Milner L, Field JA. Anaerobic oxidation of arsenite linked to chlorate reduction. Appl Environ Microbiol. 2010;76:6804-11.

42. Yan $X$, Luo $X$, Zhao M. Metagenomic analysis of microbial community in uranium-contaminated soil. Appl Microbiol Biotechnol. 2016;100:299-310.

43. Hou S, Ai C, Zhou W, Liang G, He P. Structure and assembly cues for rhizospheric nirk- and nirS-type denitrifier communities in long-term fertilized soils. Soil Biol Biochem. 2018;119:32-40.

44. Li C, Xu M, Lu Y, Fang F, Cao J. Comparative analysis of microbial community between different cathode systems of microbial fuel cells for denitrification. Environ Technol. 2016;37:752-61.

45. Zecchin S, Corsini A, Martin M, Cavalca L. Influence of water management on the active rootassociated microbiota involved in arsenic, iron, and sulfur cycles in rice paddies. Appl Microbiol Biot. 2017;101:6725-38.

46. Cai L, Liu G, Rensing C, Wang G. Genes involved in arsenic transformation and resistance associated with different levels of arsenic-contaminated soils. BMC Microbiol. 2009;9:4.

47. Kudo K, Yamaguchi N, Makino T, Ohtsuka T, Kimura K, Dong DT, et al. Release of arsenic from soil by a novel dissimilatory arsenate-reducing bacterium, Anaeromyxobactersp. strain PSR-1. Appl Environ Microbiol. 2013;79:4635-42.

48. Lin Y, Fan H, Hao X, Johnstone L, Hu Y, Wei G, et al. Draft genome sequence of Halomonas sp. strain HAL1, a moderately halophilic arsenite-oxidizing bacterium isolated from gold-mine soil. J Bacteriol. 2012;194:199-200.

49. Methe BA, Nelson KE, Eisen JA, Paulsen IT, Nelson W, Heidelberg JF, et al. Genome of Geobacter sulfurreducens: metal reduction in subsurface environments. Science. 2003;302:1967-9. 
50. Neufeld JD, Dumont MG, Vohra J, Murrell JC. Methodological considerations for the use of stable isotope probing in microbial ecology. Microb Ecol. 2006;53:435-42.

51. Okkenhaug G, Zhu YG, He J, Li X, Luo L, Mulder J. Antimony (Sb) and arsenic (As) in Sb mining impacted paddy soil from Xikuangshan, China: differences in mechanisms controlling soil sequestration and uptake in rice. Environ Sci Technol. 2012;46:3155-62.

52. Sun W, Sun X, Li B, Haggblom MM, Han F, Xiao E, et al. Bacterial response to antimony and arsenic contamination in rice paddies during different flooding conditions. Sci Total Environ. 2019;675:27385.

53. Zhang J, Zhou W, Liu B, He J, Shen Q, Zhao FJ. Anaerobic arsenite oxidation by an autotrophic arsenite-oxidizing bacterium from an arsenic-contaminated paddy soil. Environ Sci Technol. 2015;49:5956-64.

54. Qiao JT, Li XM, Li FB. Roles of different active metal-reducing bacteria in arsenic release from arsenic-contaminated paddy soil amended with biochar. J Hazard Mater. 2018;344:958-67.

55. Sanz E, Muñoz-Olivas R, Cámara C, Sengupta MK, Ahamed S. Arsenic speciation in rice, straw, soil, hair and nails samples from the arsenic-affected areas of Middle and Lower Ganga plain. J Environ Sci Heal A. 2007;42:1695-705.

56. Quemeneur M, Cebron A, Billard P, Battaglia-Brunet F, Garrido F, Leyval C, et al. Population structure and abundance of arsenite-oxidizing bacteria along an arsenic pollution gradient in waters of the upper isle River Basin, France. Appl Environ Microbiol. 2010;76:4566-70.

57. Sun W, Sun X, Cupples AM. Anaerobic methyl tert-butyl ether-degrading microorganisms identified in wastewater treatment plant samples by stable isotope probing. Appl Environ Microbiol. 2012;78:2973-80.

58. Sun W, Cupples AM. Diversity of five anaerobic toluene-degrading microbial communities investigated using stable isotope probing. Appl Environ Microbiol. 2012;78:972-80.

59. Klindworth A, Pruesse E, Schweer T, Peplies J, Quast C, Horn M, et al. Evaluation of general 16S ribosomal RNA gene PCR primers for classical and next-generation sequencing-based diversity studies. Nucleic Acids Res. 2013;41:e1.

60. Kozich JJ, Westcott SL, Baxter NT, Highlander SK, Schloss PD. Development of a dual-index sequencing strategy and curation pipeline for analyzing amplicon sequence data on the MiSeq Illumina sequencing platform. Appl Environ Microbiol. 2013;79:5112-20.

61. Bolyen E, Rideout JR, Dillon MR, Bokulich NA, Abnet C, Al-Ghalith GA, et al. QIIME 2: Reproducible, interactive, scalable, and extensible microbiome data science. PeerJ Preprints. 2018;6:e27295v2.

62. Callahan BJ, McMurdie PJ, Rosen MJ, Han AW, Johnson AJ, Holmes SP. DADA2: High-resolution sample inference from Illumina amplicon data. Nat Methods. 2016;13:581-3.

63. Quast C, Pruesse E, Yilmaz P, Gerken J, Schweer T, Yarza P, et al. The SILVA ribosomal RNA gene database project: improved data processing and web-based tools. Nucleic Acids Res. 2013;41:D5906. 
64. Bolger AM, Lohse M, Usadel B. Trimmomatic: a flexible trimmer for Illumina sequence data. Bioinformatics. 2014;30:2114-20.

65. Li D, Liu CM, Luo R, Sadakane K, Lam TW. MEGAHIT: an ultra-fast single-node solution for large and complex metagenomics assembly via succinct de Bruijn graph. Bioinformatics. 2015;31:1674-6.

66. Wood DE, Lu J, Langmead B. Improved metagenomic analysis with Kraken 2. BioRxiv 2019.

67. Uritskiy GV, DiRuggiero J, Taylor J. MetaWRAP-a flexible pipeline for genome-resolved metagenomic data analysis. Microbiome. 2018;6:158.

68. Kang DD, Froula J, Egan R, Wang Z. MetaBAT, an efficient tool for accurately reconstructing single genomes from complex microbial communities. PeerJ. 2015;3:e1165.

69. Parks DH, Imelfort M, Skennerton CT, Hugenholtz P, Tyson GW. CheckM: assessing the quality of microbial genomes recovered from isolates, single cells, and metagenomes. Genome Res. 2015;25:1043-55.

70. Droge J, Gregor I, McHardy AC. Taxator-tk: precise taxonomic assignment of metagenomes by fast approximation of evolutionary neighborhoods. Bioinformatics. 2015;1:817-24.

71. Aramaki T, Blanc-Mathieu R, Endo H, Ohkubo K, Kanehisa M, Goto S, et al. KofamKOALA: KEGG ortholog assignment based on profile HMM and adaptive score threshold. Bioinformatics 2019.

72. Segata N, Bornigen D, Morgan XC, Huttenhower C. PhyloPhIAn is a new method for improved phylogenetic and taxonomic placement of microbes. Nat Commun. 2013;4:2304.

\section{Figures}




\section{Treatment group}

$\because \mathrm{Sb}(\mathrm{III})+\mathrm{NO}_{3}^{-} \quad \longrightarrow \mathrm{Sb}(\mathrm{III}) \quad-\mathrm{NO}_{3}^{-} \quad \longrightarrow$ Sterile control
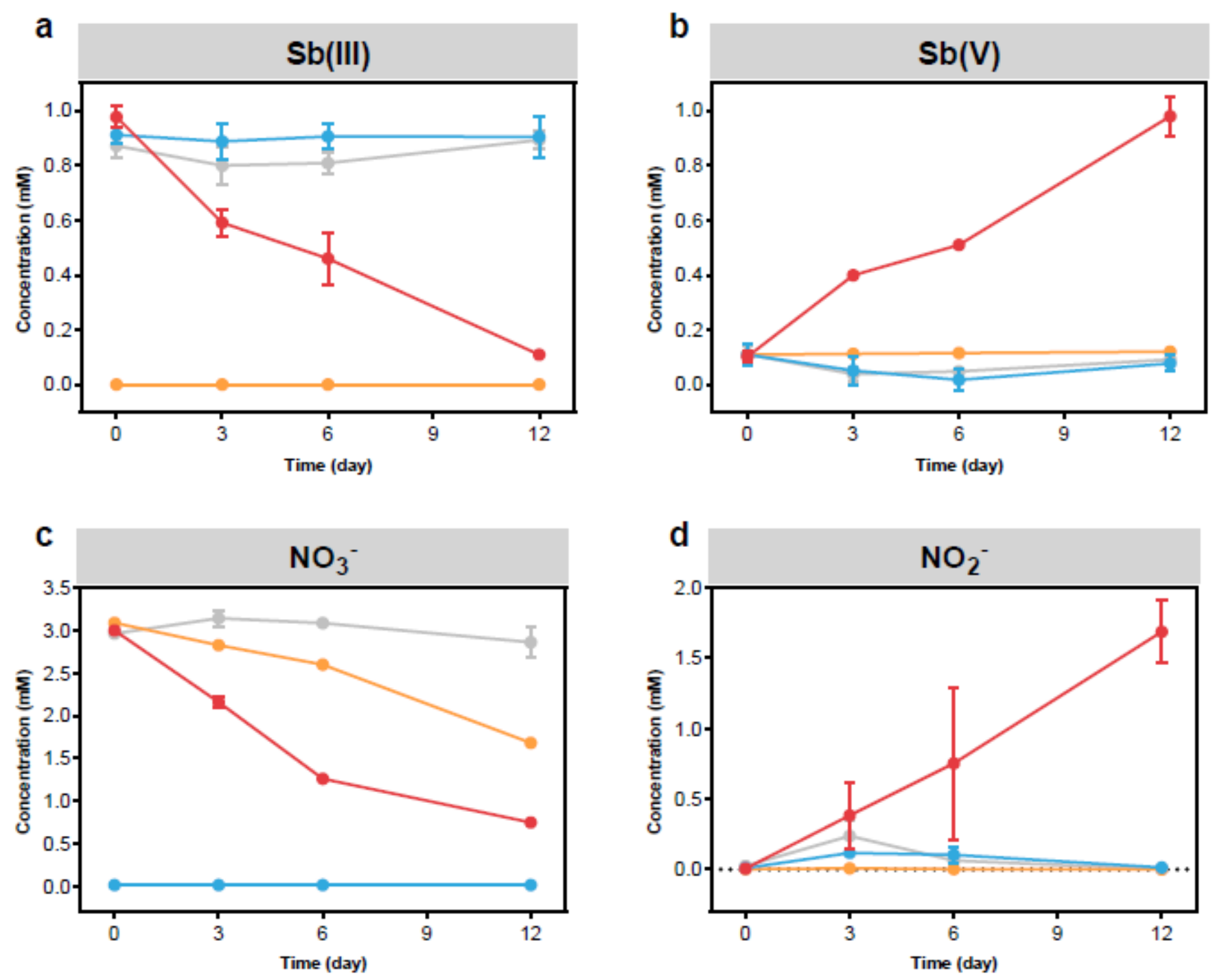

Figure 1

Transformation of $\mathrm{Sb}$ (III) (a) to $\mathrm{Sb}(\mathrm{V})$ (b) and NO3- (c) to NO2- (d) in paddy soils amended with $\mathrm{Sb}$ (III) and/or NO3-. Sterile controls were performed with soils autoclaved before incubation. Data are shown in mean $\pm S E(n=3)$. 
a

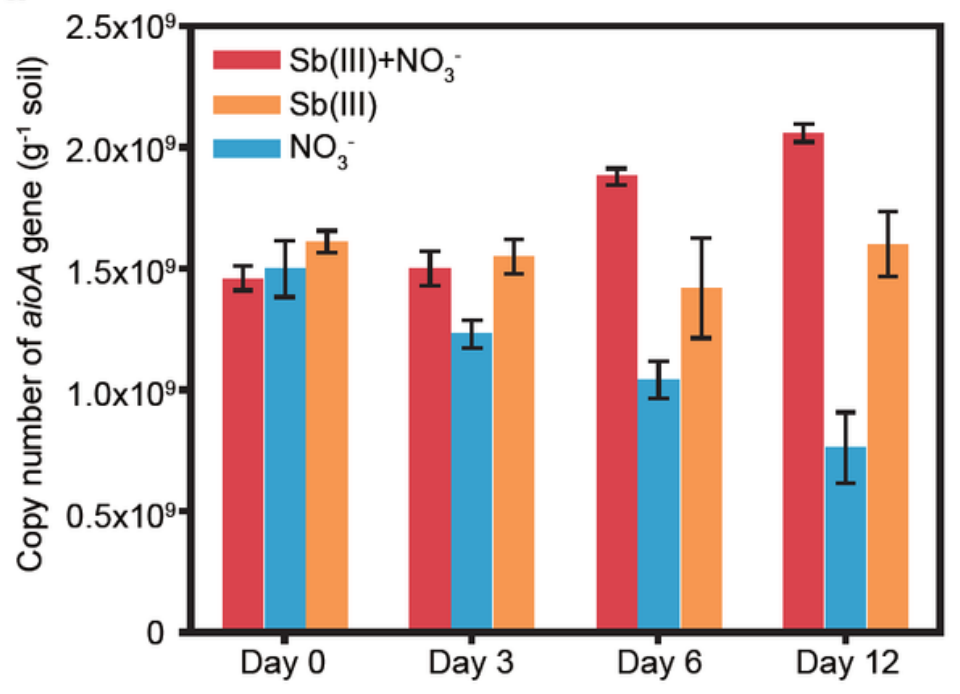

b

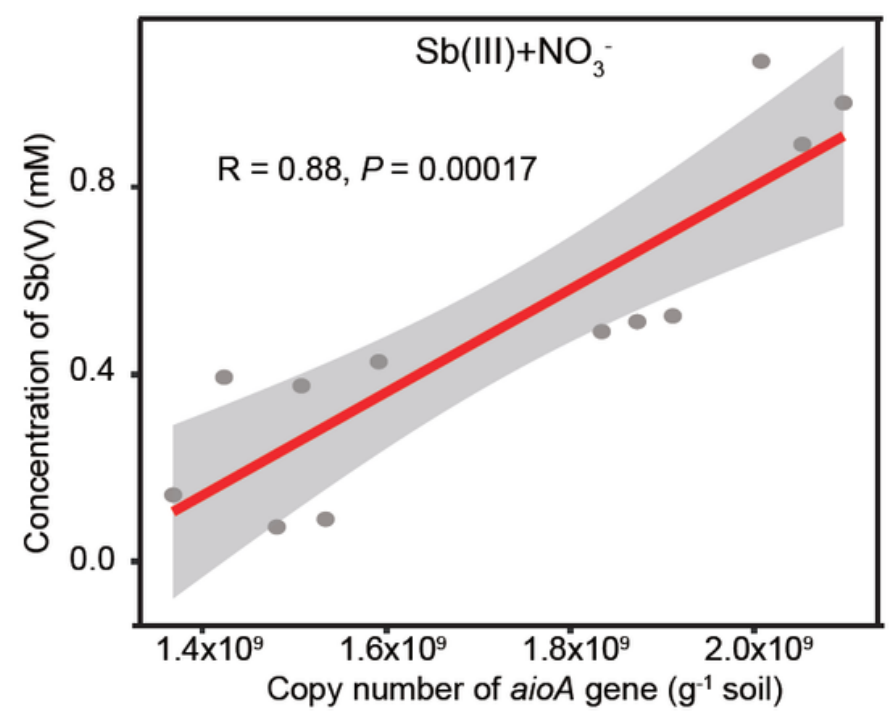

Figure 2

Abundance of the aioA gene (mean $\pm \mathrm{SE}(\mathrm{n}=3)$ ) in treatments amended with $\mathrm{Sb}$ (III) and/or NO3- (a) and the correlation between copy number of the aioA gene and the concentration of $\mathrm{Sb}(\mathrm{V})$ in treatment amended with both $\mathrm{Sb}(\mathrm{III})$ and NO3- (b) under anoxic conditions.

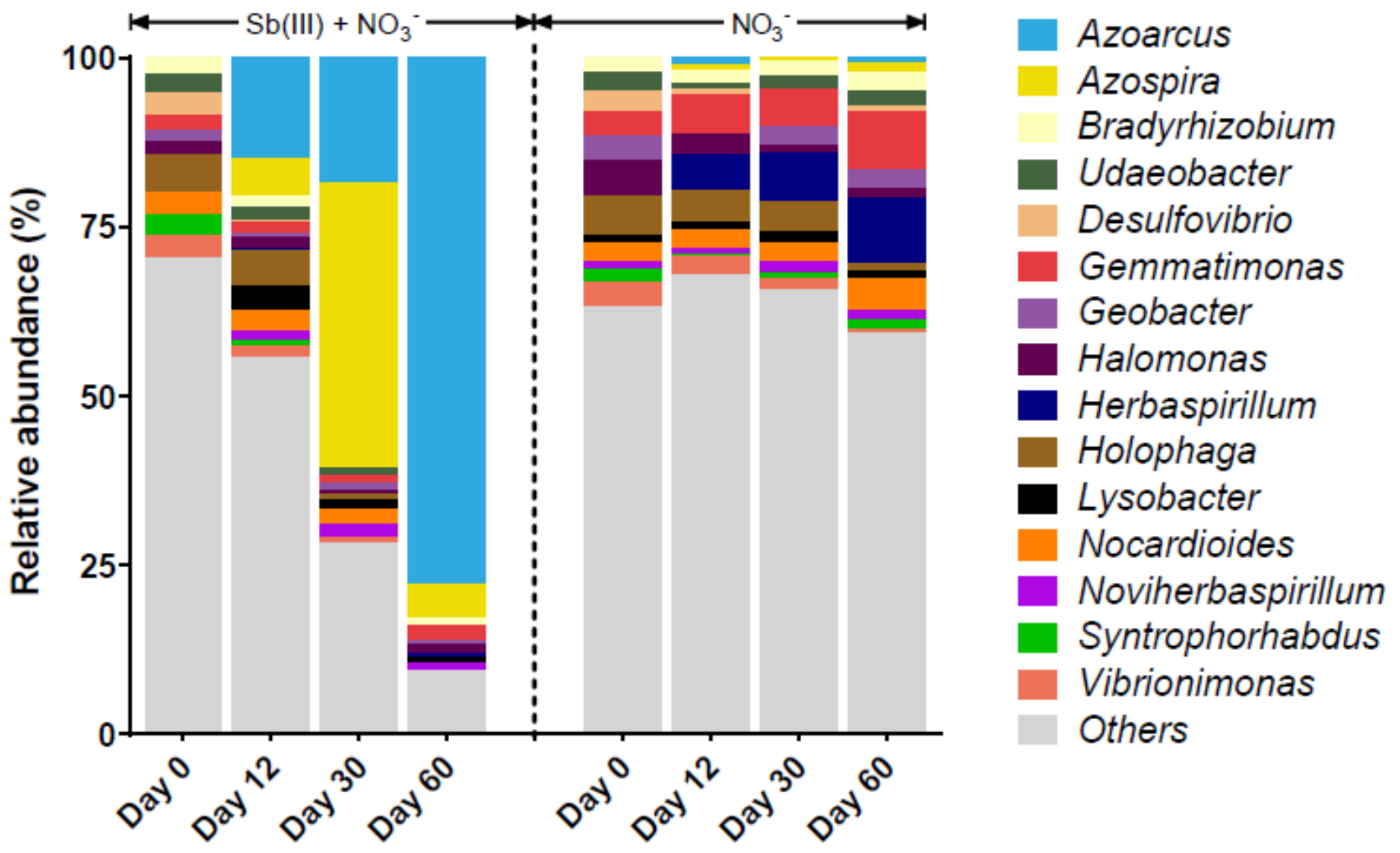

Figure 3 
Effects of $\mathrm{Sb}$ (III) and NO3- amendment on bacterial community composition based on partial 16S rRNA gene sequencing represented by the most abundant genera (top 15). Data are shown as average of triplicates (the standard deviations are listed in the text).
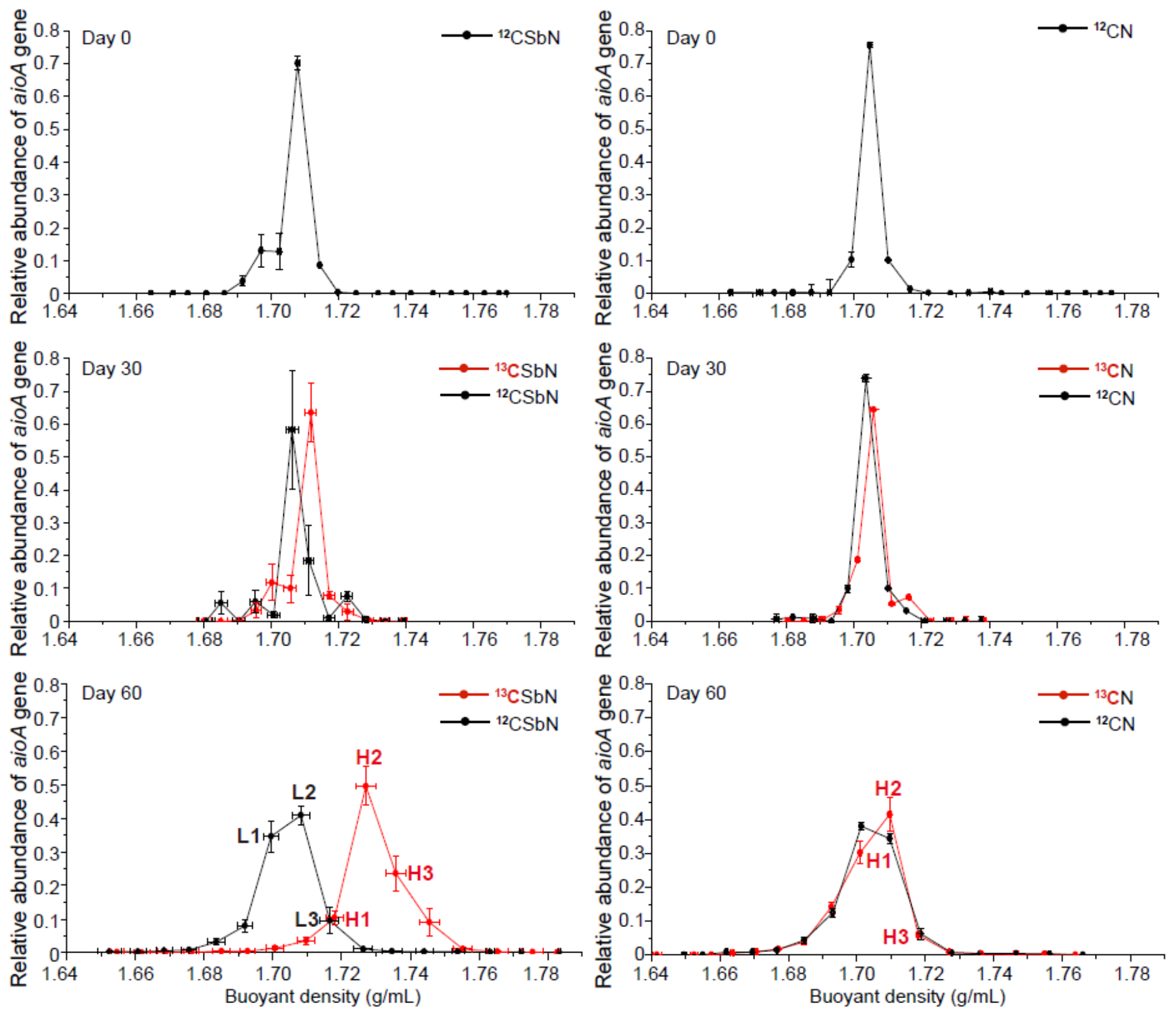

Figure 4

Relative abundance of the aioA gene in fractions collected from the $13 / 12 \mathrm{CSbN}$ and $13 / 12 \mathrm{CN}$ treatments at day 0, 30 and 60. L1-L3 represent the representative light fractions with the maximum aioA genes from the $12 \mathrm{CSbN}$ treatment, and $\mathrm{H} 1-\mathrm{H} 3$ represent the representative heavy fractions with the maximum aioA genes from the $13 \mathrm{CSbN}$ and $13 \mathrm{CN}$ treatments. Vertical and horizontal bars represent standard errors $(n=3)$ of the relative abundance of the aioA gene and the buoyant density of the fractions, respectively. 
a.

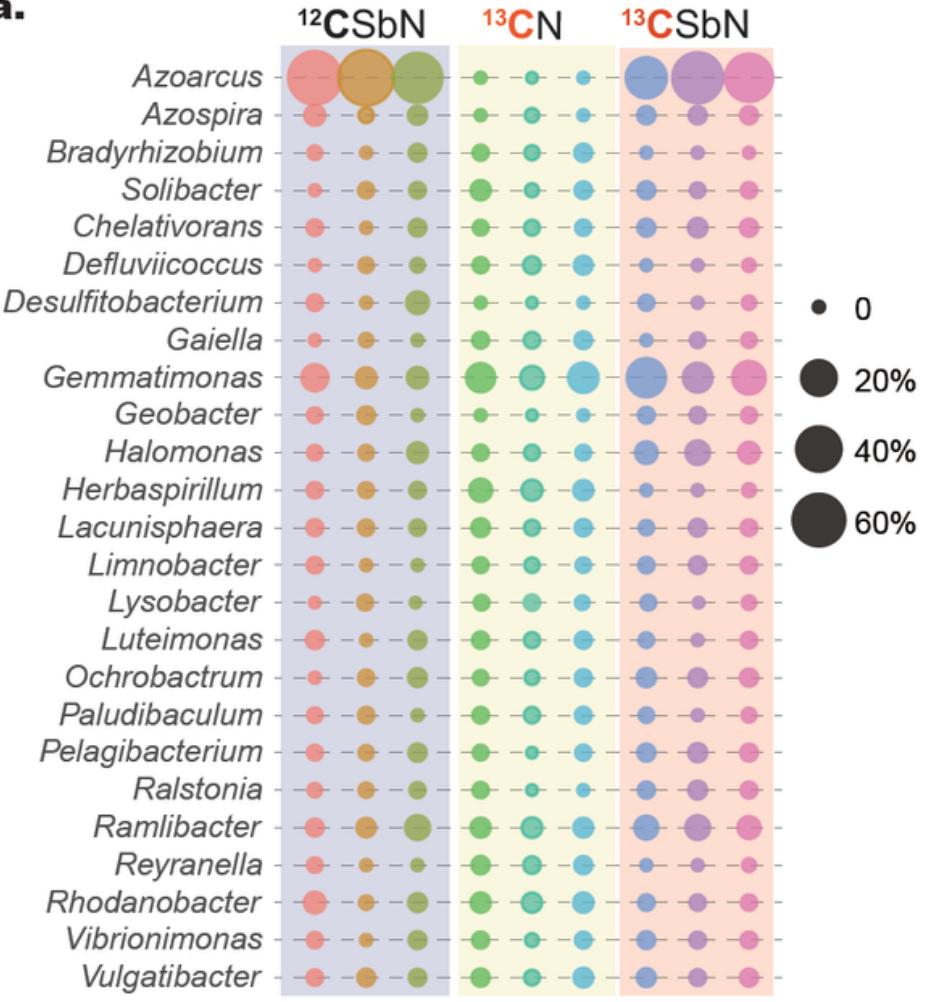

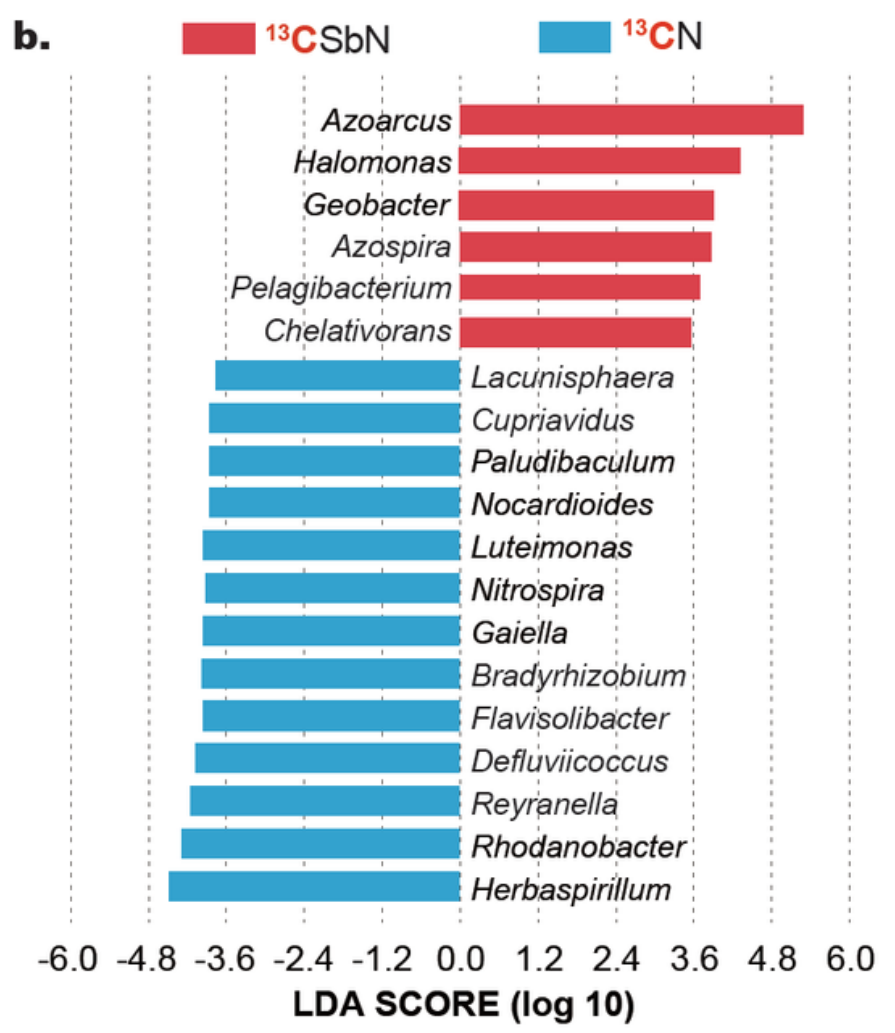

\section{Figure 5}

Bacterial community composition represented by the most abundant genera (top 25) in the heavy DNA fractions from 13CSbN and 13CN and in the light DNA fractions from the 12CSbN treatment at day 60 . Relative abundances of genera were shown as the bubble plot (a). Each bubble stands for representative fractions from one culture, and triplicate cultures were sequenced for each treatment. Linear discriminant analysis effect size (LEFSe) showed differentially abundant genera between the heavy fractions from $13 \mathrm{CSbN}$ and $13 \mathrm{CN}$ treatments $(P<0.05$ and LDA score $>2.0)(b)$. 


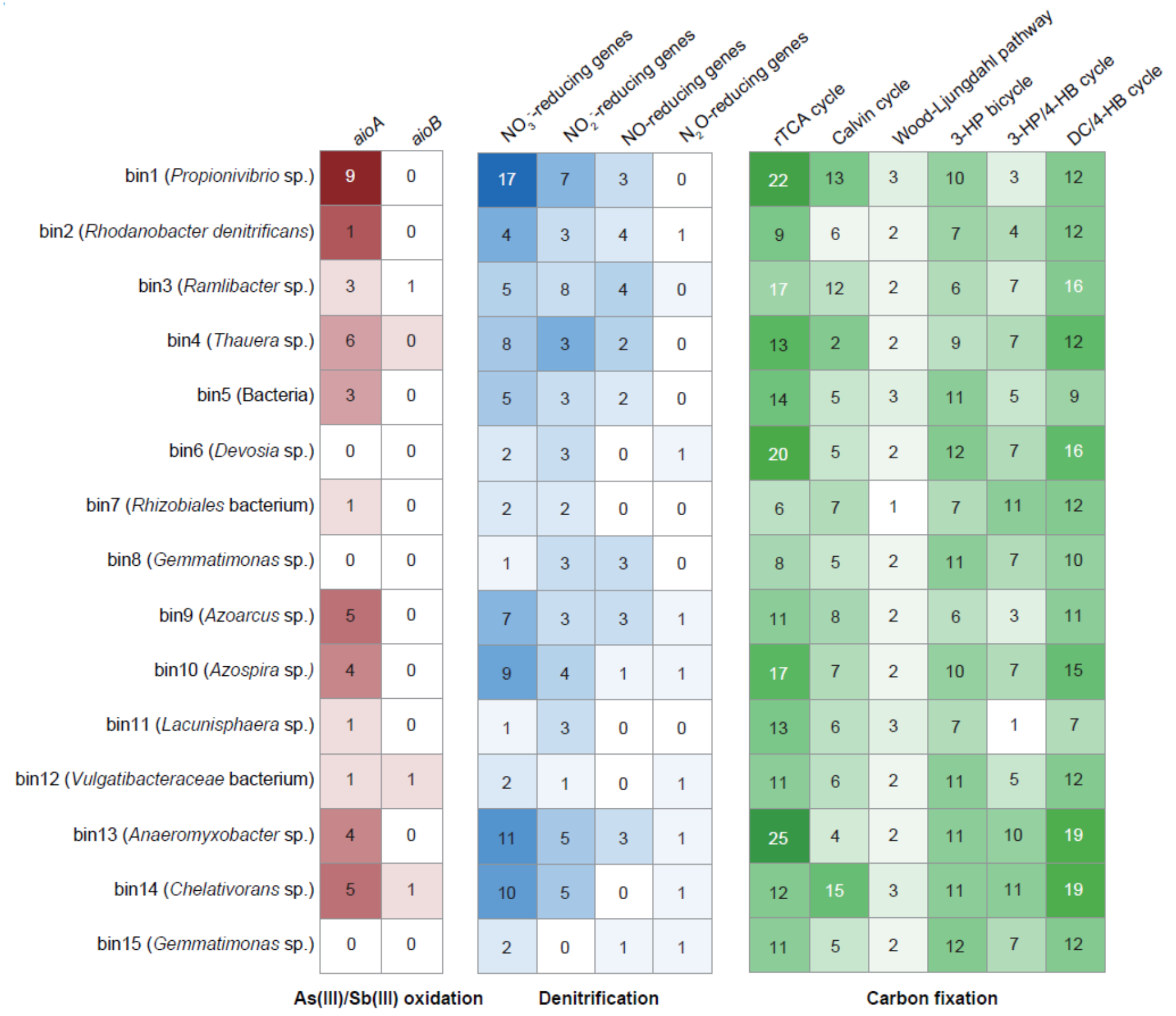

\section{Figure 6}

Counts of genes responsible for $\mathrm{Sb}$ (III) oxidation, denitrification and carbon fixation detected in the assembled bins according to shotgun metagenomic sequencing of heavy DNA fractions from the $13 \mathrm{CSbN}$ treatment. 